\title{
Variation of MODIS Reflectance and Vegetation Indices with Viewing Geometry and Soybean Development
}

\author{
FÁBIO M. BREUNIG, LÊNIO S. GALVÃO, ANTÔNIO R. FORMAGGIO and JOSÉ C.N. EPIPHANIO
}

Instituto Nacional de Pesquisas Espaciais (INPE), Divisão de Sensoriamento Remoto, Caixa Postal 515, 12245-970 São José dos Campos, SP, Brasil

Manuscript received on July 8, 2010; accepted for publication on March 22, 11

\begin{abstract}
Directional effects introduce a variability in reflectance and vegetation index determination, especially when large field-of-view sensors are used (e.g., Moderate Resolution Imaging Spectroradiometer - MODIS). In this study, we evaluated directional effects on MODIS reflectance and four vegetation indices (Normalized Difference Vegetation Index - NDVI; Enhanced Vegetation Index - EVI; Normalized Difference Water Index - NDWI 1640 and $\mathrm{NDWI}_{2120}$ ) with the soybean development in two growing seasons (2004-2005 and 2005-2006). To keep the reproductive stage for a given cultivar as a constant factor while varying viewing geometry, pairs of images obtained in close dates and opposite view angles were analyzed. By using a nonparametric statistics with bootstrapping and by normalizing these indices for angular differences among viewing directions, their sensitivities to directional effects were studied. Results showed that the variation in MODIS reflectance between consecutive phenological stages was generally smaller than that resultant from viewing geometry for closed canopies. The contrary was observed for incomplete canopies. The reflectance of the first seven MODIS bands was higher in the backscattering. Except for the EVI, the other vegetation indices had larger values in the forward scattering direction. Directional effects decreased with canopy closure. The NDVI was lesser affected by directional effects than the other indices, presenting the smallest differences between viewing directions for fixed phenological stages.
\end{abstract}

Key words: NDWI, EVI, NDVI, remote sensing, directional effects.

\section{INTRODUCTION}

In Earth science studies with satellite images, vegetation indices are generally used to characterize the dynamics of vegetation and to estimate biophysical attributes such as Leaf Area Index (LAI) (Knyazikhin et al. 1998, Myneni et al. 2002, Jackson et al. 2004, Rizzi et al. 2006, Yi et al. 2008, Jiang et al. 2010). Biophysical attributes estimates from empirical models using vegetation indices are

Correspondence to: Fábio Marcelo Breunig

E-mail: breunig@dsr.inpe.br especially important in areas where cloud cover is a major limiting factor to achieve high quality data for physical models.

In theory, an ideal vegetation index should maximize the green vegetation response while minimizing the influence of other undesirable factors on canopy reflectance. In practice, this ideal index does not exist, which explains the great number of indices proposed after the first publication of the Normalized Difference Vegetation Index (NDVI) (Rouse et al. 1973). For example, when compared 
to the NDVI, the Enhanced Vegetation Index (EVI) was formulated to improve the sensitivity to high biomass and to reduce the atmosphere and soil background effects (Huete et al. 2002, Jiang et al. 2008). The Normalized Difference Water Index (NDWI) was designed to detect green vegetation through the indirect measurement of the leaf/ canopy water content (Gao 1996, Jackson et al. 2004). In spite of these modifications, most of the vegetation indices are still sensitive to directional effects (Wardley 1984, Myneni and Williams 1994, Epiphanio and Huete 1995, Walter-Shea et al. 1997, Aparicio et al. 2004, Chen et al. 2005, Galvão et al. 2009, and references therein).

Directional effects are especially important when using large field-of-view (FOV $= \pm 55^{\circ}$ ) sensors like the Moderate Resolution Imaging Spectroradiometer (MODIS) onboard the Terra and Aqua platforms (Meyer et al. 1995, Miura et al. 2000, Gao et al. 2003, Xiong et al. 2005, Doraiswamy et al. 2005, Jiang et al. 2010). This instrument is very important for global scale studies because its nearly daily coverage increases the chances of acquiring cloud-free images for an adequate temporal series analysis. On the other hand, for the same vegetation type and phenological stage, changes in MODIS illumination-viewing geometry (solar and sensor azimuth and zenith angles) can result in strong reflectance differences for the sensor that impact on the vegetation index determination and on resultant empirical LAI estimates.

LAI estimates can be critical over Brazilian soybean areas because the crop development is coincident with the peak of cloud cover. As a result, most of the MODIS LAI estimates (e.g. MOD15 product) are performed using empirical relationships between the NDVI and LAI(the "BackupAlgorithm") rather than radiative transfer modeling (the "Main Algorithm") (Rizzi and Rudorff 2007, Rizzi et al. 2006). Alternatively, LAI can be estimated from the NDWI or EVI, but there are no studies addressing the sensitivity of these indices to directional effects when compared to the NDVI.
In this investigation, a temporal series of MODIS images was used to evaluate the directional effects on reflectance and vegetation indices (NDVI, EVI and NDWIs) as a function of the soybean development in two growing seasons (2004-2005 and 2005-2006). The objective was to identify the less affected vegetation index by such effects.

\section{MATERIALS AND METHODS}

\section{STUDY AREA AND AGRONOMIC DATA}

The study area (Tanguro farm; 11,000 hectares) is located in Querência municipality, state of Mato Grosso (central Brazil), between the coordinates S12.679/W52.421 (upper left corner) and S12.887/W52.298 (lower right corner). This area is characterized by a flat topography $(350 \mathrm{~m}$ of altitude) with the predominance of Latossolo Vermelho-Amarelo distrófico (Typic Acrustox in the USA Soil Taxonomy). The climate is tropical with mean temperature of $26^{\circ} \mathrm{C}$ and annual rainfall of $1850 \mathrm{~mm}$. The native vegetation comprises the transition between the Brazilian savannas (Cerrado) and the Amazonian tropical rainforest.

Five soybean cultivars predominated at the Tanguro farm in the two growing seasons (20042005 and 2005-2006) (Table I). Most of the cultivars were planted with constant row spacing $(45 \mathrm{~cm})$ in the beginning of November and harvested at the end of March. In general, maximum crop development was observed between January and February. Perdiz was the dominant cultivar in both seasons. Inspection of TRMM (Tropical Rainfall Measuring Mission) data showed that the rainy season started earlier in 2004-2005.

A detailed map of soybean cultivars was provided by the farm administration for both growing seasons. Using this map, we selected only cultivars from well-defined clusters of spatially adjacent soybean plots. For example, in the 2005-2006 growing season, the total size of plots 
TABLE I

Agronomic data for some soybean cultivars planted at the Tanguro farm in the 2004-2005 and 2005-2006 growing seasons.

\begin{tabular}{l|c|c|c|c|c|c}
\hline & \multicolumn{2}{|c|}{ 2004-2005 } & \multicolumn{3}{c}{ 2005-2006 } \\
\hline Cultivar & $\begin{array}{c}\text { Planting date } \\
\text { MM/DD,YY }\end{array}$ & $\begin{array}{c}\text { Harvesting date } \\
\text { MM/DD,YY }\end{array}$ & $n$ & $\begin{array}{c}\text { Planting date } \\
\text { MM/DD,YY }\end{array}$ & $\begin{array}{c}\text { Harvesting date } \\
\text { MM/DD,YY }\end{array}$ & $N$ \\
\hline Perdiz & $\begin{array}{c}10 / 30-11 / 09, \\
2004\end{array}$ & $\begin{array}{c}03 / 07-04 / 09, \\
2005\end{array}$ & 47 & $\begin{array}{c}10 / 25-11 / 05, \\
2005\end{array}$ & $\begin{array}{c}03 / 01-03 / 28, \\
2005\end{array}$ & 30 \\
\hline $\begin{array}{l}\text { Monsoy } \\
9010\end{array}$ & $\begin{array}{c}11 / 14-11 / 16, \\
2004\end{array}$ & $\begin{array}{c}03 / 24-03 / 30, \\
2005\end{array}$ & 15 & $\begin{array}{c}11 / 11-11 / 13, \\
2005\end{array}$ & $\begin{array}{c}03 / 02-04 / 08, \\
2006\end{array}$ & 12 \\
\hline Tabarana & - & - & - & $\begin{array}{c}11 / 08-11 / 14, \\
2005\end{array}$ & $\begin{array}{c}03 / 20-04 / 09, \\
2006\end{array}$ & 13 \\
\hline $\begin{array}{l}\text { Monsoy } \\
8914\end{array}$ & - & - & - & $\begin{array}{c}11 / 02-11 / 17, \\
2005\end{array}$ & $\begin{array}{c}03 / 09-03 / 20, \\
2006\end{array}$ & 17 \\
\hline $\begin{array}{l}\text { Monsoy } \\
8411\end{array}$ & $10 / 29-11 / 01$, & $02 / 21-03 / 13$, & 8 & - & - & - \\
\hline
\end{tabular}

$n$ is the number of soybean fields sensed by MODIS for each cultivar.

ranged from 300 hectares (12 pixels) for Monsoy 9010 to 750 hectares (30 pixels) for Perdiz. To avoid subpixel mixture and surface land cover heterogeneity, a minimum margin of $500 \mathrm{~m}$ from the border of the plots was established to select the representative pixels for data analysis.

\section{Modis ReFLECTANCE DATA}

The investigation was performed using MODIS daily surface reflectance images and derived vegetation indices (NDVI, EVI and NDWIs). The Collection 5 product "Surface Reflectance Daily L2G Global 1km and 500m" (MOD09GA) was obtained from the Warehouse Inventory Search Tool (WIST). The MODIS Reprojection Tool (MRT) (Dwyer and Schmidt 2006) converted the sinusoidal projection into planar coordinates (UTM WGS-84). A total of 19 (2004-2005) and
20 (2005-2006) cloud free images with a pixel size of $500 \mathrm{~m}$ was selected from November to March of each season. A detailed list of the 20 images representing the 2005-2006 growing season (planting to the harvesting period) is presented in Table II. Negative angles indicate backscattering (Sun behind the sensor) or the predominance of sunlit canopy components for the MODIS. Positive angles indicate forward scattering (sensor in front of the Sun), with the predominance of shadowed canopy components for the sensor.

\section{DATA ANALYSIS}

Three main steps were used in the data analysis: a) analysis of the reflectance and vegetation index variation as a function of the soybean development; b) evaluation of the directional effects on reflectance and vegetation indices for fixed phenological stages; 
TABLE II

List of MODIS images used in the analysis of the 2005-2006 soybean growing season. Bolded and italicized dates refer to pair of MODIS images with opposite view angles acquired over incomplete (December) and closed (January) canopies.

\begin{tabular}{l|c|c|c}
\hline \multicolumn{1}{c|}{ Date } & $\begin{array}{c}\text { View } \\
\text { Angle ( }\end{array}$ & Direction & Days after planting* \\
\hline November 04, 2005 & -41 & Backscattering & Planting period \\
\hline November 06, 2005 & -56 & Backscattering & Planting period \\
\hline November 07, 2005 & +24 & Forward scattering & Planting period \\
\hline November 09, 2005 & -4 & Backscattering & Planting period \\
\hline November 21, 2005 & +45 & Forward scattering & 12 \\
\hline December 21, 2005 & +58 & Forward scattering & 42 \\
\hline December 22, 2005 & -41 & Backscattering & 43 \\
\hline December 25, 2005 & +24 & Forward scattering & 46 \\
\hline January 14, 2006 & -32 & Backscattering & 66 \\
\hline January 19, 2006 & +8 & Forward scattering & 71 \\
\hline January 21, 2006 & -20 & Backscattering & 73 \\
\hline January 22, 2006 & +58 & Forward scattering & 74 \\
\hline January 23, 2006 & -42 & Backscattering & 75 \\
\hline January 24, 2006 & +44 & Forward scattering & 76 \\
\hline January 25, 2006 & -57 & Backscattering & 77 \\
\hline January 29, 2006 & +63 & Forward scattering & 81 \\
\hline February 09, 2006 & +44 & Forward scattering & 102 \\
\hline February 19, 2006 & -62 & Backscattering & Harvesting period \\
\hline February 22, 2006 & -19 & Backscattering & \\
\hline March 21, 2006 & -50 & Backscattering & \\
\hline & & & \\
\hline
\end{tabular}

* November 9 served as reference for planting date.

and c) sensitivity analysis of the vegetation indices to directional effects. The MODIS band positioning and equations/references for the studied vegetation indices are presented in Table III. Unfortunately, the original formulation of the NDWI (Gao 1996) could not be applied to MODIS due to stripping (noisy data) associated with band 5 (1230-1250 $\mathrm{nm})$. We then used two NDWI variants proposed by Chen et al. (2005) to address this problem, in which MODIS band 5 was replaced in the Gao's equation by bands 6 (1628-1652 nm; henceforth named $\left.\mathrm{NDWI}_{1640}\right)$ and 7 (2105-2155 nm; NDWI $\left.{ }_{2120}\right)$.

In the first step, we used the first seven MODIS bands to characterize temporal variation in reflectance and plotted the derived NDVI, EVI, $\mathrm{NDWI}_{1640}$ and $\mathrm{NDWI}_{2120}$ for different soybean cultivars. A total of 70 (2004-2005) and 72 (20052006) agricultural fields of the soybean varieties had their reflectance values extracted and the vegetation indices calculated for each one of the 
TABLE III

First seven MODIS bands and derived vegetation indices under analysis.

\begin{tabular}{|c|c|c|c|}
\hline $\begin{array}{l}\text { Vegetation } \\
\text { Index }\end{array}$ & Formula & Reference & $\begin{array}{l}\text { First seven } \\
\text { MODIS Bands }\end{array}$ \\
\hline NDVI & $(b 2-b 1) /(b 2+b 1)$ & Rouse et al. (1973) & \multirow{4}{*}{$\begin{array}{l}b 1(620-670 \mathrm{~nm}) \\
b 2(841-876 \mathrm{~nm}) \\
b 3(459-479 \mathrm{~nm}) \\
b 4(545-565 \mathrm{~nm}) \\
b 5(1230-1250 \mathrm{~nm}) \\
b 6(1628-1652 \mathrm{~nm}) \\
b 7(2105-2155 \mathrm{~nm})\end{array}$} \\
\hline EVI & $2.5\left(\frac{(b 2-b 1)}{(b 2+6 * b 1-7.5 * b 3+1)}\right)$ & Huete et al. (2002) & \\
\hline $\mathrm{NDWI}_{1640}$ & $(b 2-b 6) /(b 2+b 6)$ & Chen et al. (2005) & \\
\hline $\mathrm{NDWI}_{2120}$ & $(b 2-b 7) /(b 2+b 7)$ & Chen et al. (2005) & \\
\hline
\end{tabular}

dates comprising the life cycle of soybean (Table I). Results with the crop development were analyzed considering the viewing direction of MODIS data acquisition (backscattering and forward scattering).

In order to keep the reproductive stage for a given soybean cultivar as a constant factor whilst varying the viewing geometry, two pairs of images obtained at opposite view angles and consecutive dates were analyzed in the second step to evaluate the directional effects on reflectance and vegetation indices. For example, dates in italic in Table II indicated pairs of images selected for the 2005-2006 growing season (December 21 and 22, 2005; January 23 and 24, 2006). Scatter plots of the reflectance and vegetation indices were then generated for each pair of dates representing incomplete and closed soybean canopies as a function of viewing direction.

The last step in data analysis included the use of two different approaches to evaluate the sensitivity of vegetation indices to directional effects. First, a statistical approach based on the non-parametric Wilcoxon Signed Rank Test (WSRT) (Wilcoxon 1945) was used to verify differences between the vegetation indices calculated from consecutive dates (same phenological stage) and opposite viewing directions (backscattering and forward scattering). In order to reduce the impact of the small sample size and strength of the analysis, a bootstrap analysis with 1000 repetitions was adopted. The inspection of $\mathrm{Z}$ and $p$-values provided an indication of the differences of a given vegetation index between the populations (backscattering and forward scattering). The second approach in the sensitivity analysis was based on the angular normalization of the four vegetation indices calculated for the same reproductive stage and from opposite view directions through the equation: $\left(\mathrm{VI}_{\text {forward scattering }}-\mathrm{VI}_{\text {backscattering }}\right) /\left(\mathrm{VI}_{\text {forward scattering }}\right.$ $+\mathrm{VI}_{\text {backscattering }}$ ). Angular differences close to zero indicate a lesser sensitivity of the vegetation indices to directional effects. To take into consideration the impact of other potential factors on results (e.g., atmosphere residual effects and pixel mixture), the frequency of the pixels with the lowest angular differences for each index was computed. Results from the two approaches (Wilcoxon Signed Rank Test and angular normalization) were compared to each other.

\section{RESULTS AND DISCUSSION}

TEMPORAL VARIATION IN SOYBEAN REFLECTANCE AND VEGETATION INDICES

Temporal variation in MODIS reflectance between consecutive phenological stages was generally smaller than that resultant from viewing geometry for closed canopies (Figure 1a), but the contrary was 
observed for incomplete canopies (Figure 1b). For example, the Perdiz cultivar showed reflectance differences up to $4 \%$ in the near infrared (NIR) interval(MODIS band 2;841-876nm) due to distinct phenological stages. Such differences increased to values up to $20 \%$ when this soybean cultivar was sensed by MODIS at the same phenological stage, but with opposite backscattering (e.g., $-42^{\circ}$ view angle for January 23, 2006) and forward scattering (e.g., $+44^{\circ}$ view angle for January 24, 2006) directions (Figure 1a). On the other hand, Monsoy 9010 presented reflectance differences up to $25 \%$ (phenological stages) and up to $15 \%$ (viewing geometry) in the NIR from December to January (Figure 1b).
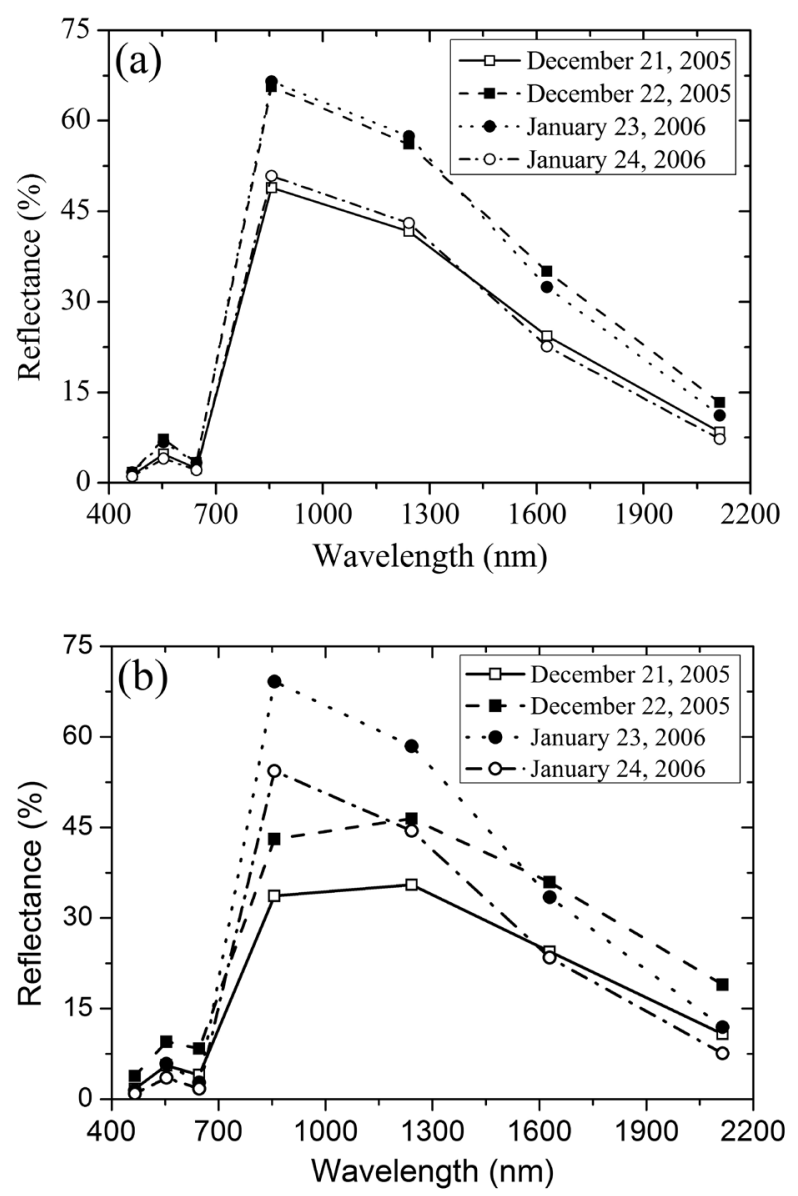

Figure 1 - Mean MODIS reflectance spectra of (a) Perdiz and (b) Monsoy 9010 soybean cultivars in two development stages of the 2005-2006 growing season.
As expected, the reflectance of the first seven studied MODIS bands was much higher in the backscattering direction due to larger amounts of sunlit canopy components viewed by the sensor. For example, in spite of the view angles listed in Table II, the MODIS red (Figure 2a) and NIR (Figure $2 b$ ) reflectance values were always higher in the backscattering direction along the entire cycle of soybean development in 2005-2006, including the planting period. A similar pattern was observed in 2004-2005.

After the NDVI calculation (Figure 3a), spectral differences due to viewing geometry were greatly reduced. In contrast to reflectance values, because the red radiation was much more affected by shadows than the NIR radiation (Leblon et al. 1996, Aparicio et al. 2004) and due to the greater dependence of the NDVI to the red band, the NDVI values were higher in the forward scattering direction at all stages of the soybean development. The same behavior was not observed for the EVI (Figure 3b) that presented larger values in the backscattering and greater dependence on the NIR band $\left(R^{2}=0.89\right)$. Because of these behaviors, the 16-day composite MODIS vegetation index images (product MODIS 13Q1) may be biased in some extent by a preferential pixel selection due to directional rather than atmospheric effects, as discussed by Meyer et al. (1995), when using AVHRR data and the maximum NDVI procedure for pixel selection.

\section{DireCtional EFFECTS ON REFLECTANCE AND VEGETATION INDICES For FIXED PHENOLOGICAL STAGES}

For fixed soybean phenological stages in December 2005 (incomplete canopies) and in January 2006 (closed canopies) and for opposite viewing directions, the inspection of the scatter plots for MODIS bands (Figure 4) showed higher reflectance for backscattering pixels (filled symbols) in concordance with the results of Figure 2. Data dispersion was higher in December because 

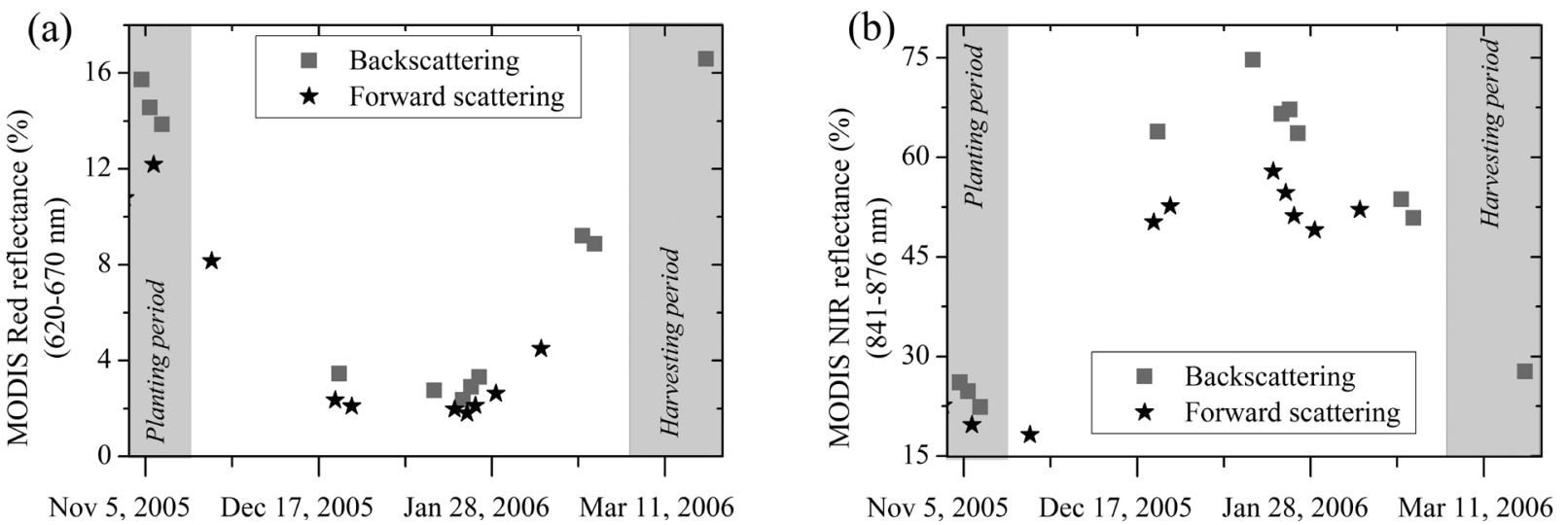

Figure 2 - Variation in reflectance as a function of the crop development (Perdiz cultivar) and viewing direction for the MODIS (a) red (620-670 $\mathrm{nm})$ and (b) near-infrared (NIR) (841-876 nm) bands.

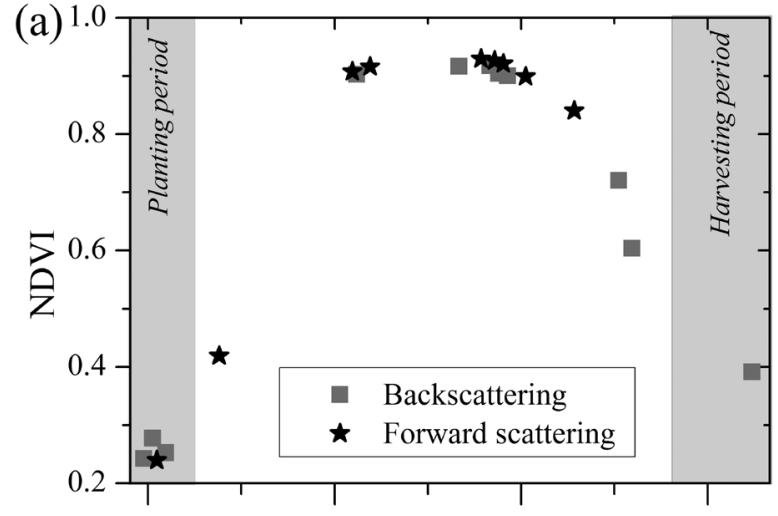

Nov 5, 2005 Dec 17, 2005 Jan 28, 2006 Mar 11, 2006

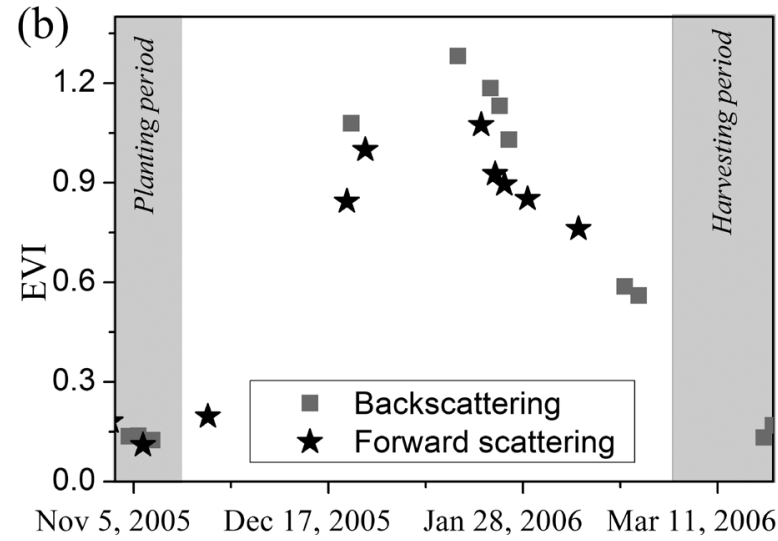

Figure 3 - Variation in the (a) NDVI and (b) EVI as a function of the crop development (Perdiz cultivar) and viewing direction.

of the stronger soil background influence on the incomplete canopy reflectance.

When plotted as a function of the soybean varieties, the NDVI showed higher values in the forward scattering direction, which presented also higher amplitude of vegetation index variation with the cultivar development, especially for Monsoy 9010 (Figure 5). This variety was sensed by MODIS in December 2005 at an earlier phenological stage than the others. In agreement with field experiments by Epiphanio and Huete (1995) and Walther-Shea et al. (1997), the results of Figure 5 showed that directional effects were stronger on the NDVI calculated over soybean incomplete canopies (December 2005) than over closed canopies (January 2006), as indicated by larger data variability at initial stages of crop development. The other VIs presented similar results (not showed).

\section{SENSITIVITY OF VEGETATION INDICES TO DiRECTIONAL EFFECTS}

Wilcoxon Signed Rank Test coefficients for the differences among vegetation indices, which were calculated at the same soybean phenological stage and in opposite forward scattering (December 21,$2005 ;+58^{\circ}$ view angle) and backscattering (December 22, 2005; $-41^{\circ}$ view angle) directions, 


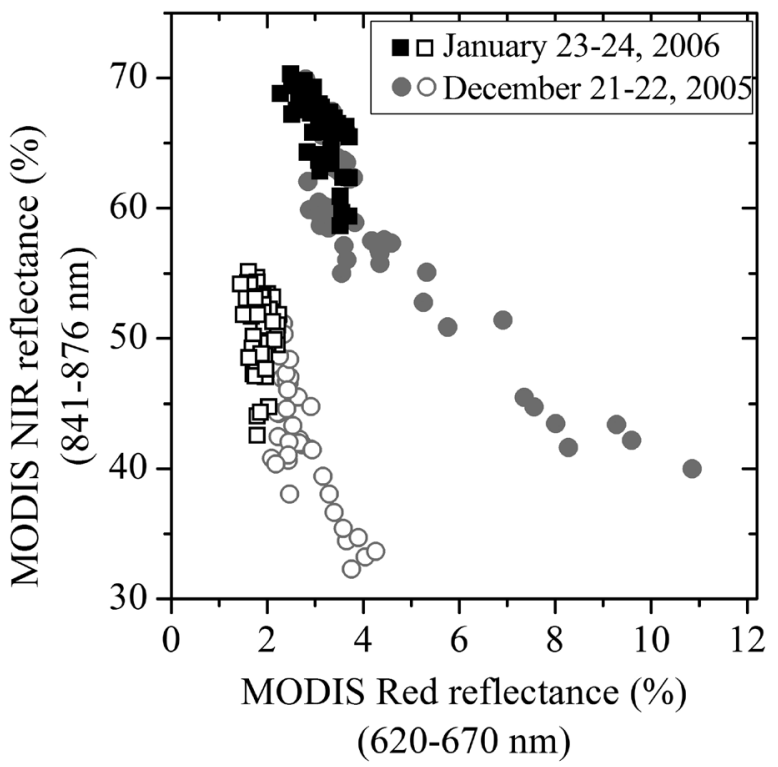

Figure 4 - Relationship between the MODIS red (620-670 nm) and near-infrared (NIR) $(841-876 \mathrm{~nm})$ reflectance for two pairs of images acquired in opposite viewing directions at incomplete (December 21 and 22, 2005) and closed (January 23 and 24, 2006) soybean canopies. Non-filled and filled symbols indicate the forward scattering and backscattering view directions, respectively.

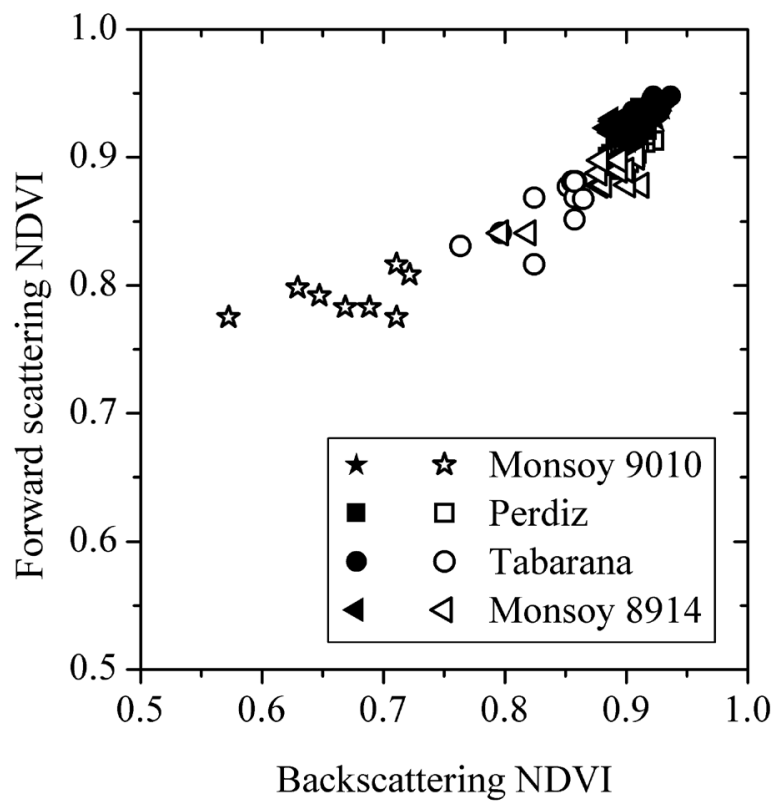

Figure 5 - The NDVI variation for different soybean varieties for two pairs of images acquired in opposite viewing directions at incomplete (December 21 and 22, 2005; non-filled symbols) and closed (January 23 and 24, 2006; filled symbols) soybean canopies.

showed that the NDVI was lesser affected by directional effects than the other indices. The NDVI presented median $\mathrm{Z}$ values closer to zero than the $\mathrm{NDWI}_{1640}, \mathrm{NDWI}_{2120}$ and EVI (Table IV). These three indices displayed the largest statistically significant differences when calculated from an opposite viewing direction and fixed phenological stages. The results (not shown) for pairs of images in the 2004-2005 growing season were similar to those of Table IV. 
TABLE IV

Wilcoxon Signed Rank Test coefficients for the differences between vegetation indices calculated at approximately similar soybean phenological stages and with opposite viewing geometries in the forward scattering (December 21, $2005 ;+58^{\circ}$ view angle) and backscattering (December 22,$2005 ;-41^{\circ}$ view angle) directions.

\begin{tabular}{|c|c|c|c|c|c|c|c|c|}
\hline \multirow{2}{*}{$\begin{array}{c}\text { Forward } \\
\text { Scattering } \\
\text { versus } \\
\text { backscattering }\end{array}$} & \multirow[b]{2}{*}{$n$} & \multicolumn{7}{|c|}{ Wilcoxon Signed Ranks Test results* } \\
\hline & & $\begin{array}{c}\text { Min. } \\
Z\end{array}$ & $\begin{array}{c}\text { Median } \\
Z\end{array}$ & $\begin{array}{c}\text { Max. } \\
Z\end{array}$ & $\begin{array}{c}Z \\
\text { S.D. }\end{array}$ & $\begin{array}{c}\text { Median } \\
P\end{array}$ & $\begin{array}{c}\text { Mean } \\
P\end{array}$ & $\begin{array}{c}p \\
\text { S.D. }\end{array}$ \\
\hline NDVI & 72 & -6.460 & -4.319 & -1.094 & 0.737 & $<0.000$ & 0.001 & 0.010 \\
\hline EVI & 72 & 6.701 & 7.273 & 7.376 & 0.098 & $<0.000$ & $<0.000$ & $<0.000$ \\
\hline $\mathrm{NDWI}_{1640}$ & 72 & -7.376 & -6.847 & -5.511 & 0.333 & $<0.000$ & $<0.000$ & $<0.000$ \\
\hline $\mathrm{NDWI}_{2120}$ & 72 & -7.376 & -7.333 & -7.066 & 0.057 & $<0.000$ & $<0.000$ & $<0.000$ \\
\hline
\end{tabular}

* After bootstrapping resampling with 1000 interactions.

Angular normalization of the vegetation indices calculated in consecutive days and in opposite viewing directions confirmed results of the Wilcoxon Signed Rank Test (Figure 6). The NDVI had average normalized values closer to zero and, thus, was lesser sensitive to directional effects than the EVI, NDWI ${ }_{1640}$ and $\mathrm{NDWI}_{2120}$. For the four studied vegetation indices, the sensitivity decreased from incomplete (December 21 and 22, 2005) to closed (January 23 and 24, 2006) soybean canopies, which was again in agreement with the

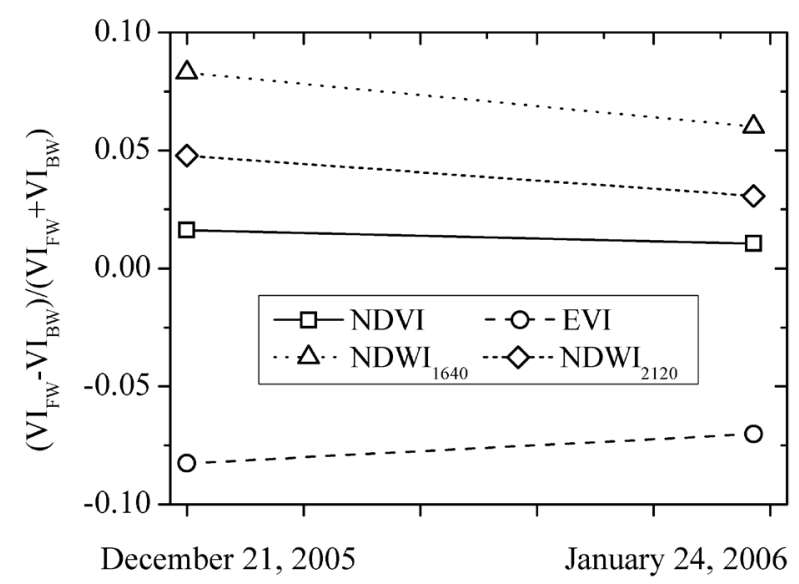

Figure 6 - Angular normalization (average values) of the four studied vegetation indices calculated in consecutive days and in opposite viewing directions at incomplete (December 21 and 22, 2005) and closed (January 23 and 24, 2006) soybean canopies. FW and BW indicate the Forward scattering and Backscattering directions, respectively. field experiment results obtained by Epiphanio and Huete (1995) and Walter-Shea et al. (1997). In the 2004-2005 growing season, a careful inspection of the angular normalized indices on a per pixel basis showed the predominance of the NDVI as the less sensitive index to directional effects for $77 \%$ and $98 \%$ of the pixels for incomplete (December 6 and 8, 2004) and closed (February 5 and 6, 2005) soybean canopies, respectively (Figure 7a). In the 2005-2006 growing season, the NDVI was the less sensitive index for 79\% (incomplete canopies; December 21 and 22, 2005) and 100\% (closed canopies; January 23 and 24, 2006) of the pixels (Figure 7b).

\section{CONCLUSION}

Variation in MODIS reflectance between consecutive phenological stages was generally smaller than that resultant from viewing geometry for closed canopies (e.g., Perdiz). The contrary was observed for incomplete canopies (e.g., Monsoy 9010). Reflectance differences up to $4 \%$ (phenological stage) and up to $20 \%$ (viewing geometry) were observed for the soybean cultivar Perdiz in the MODIS NIR band (841-876 nm). Such differences changed to $25 \%$ due to phenology and to $15 \%$ due to viewing geometry for the cultivar Monsoy 9010 . 

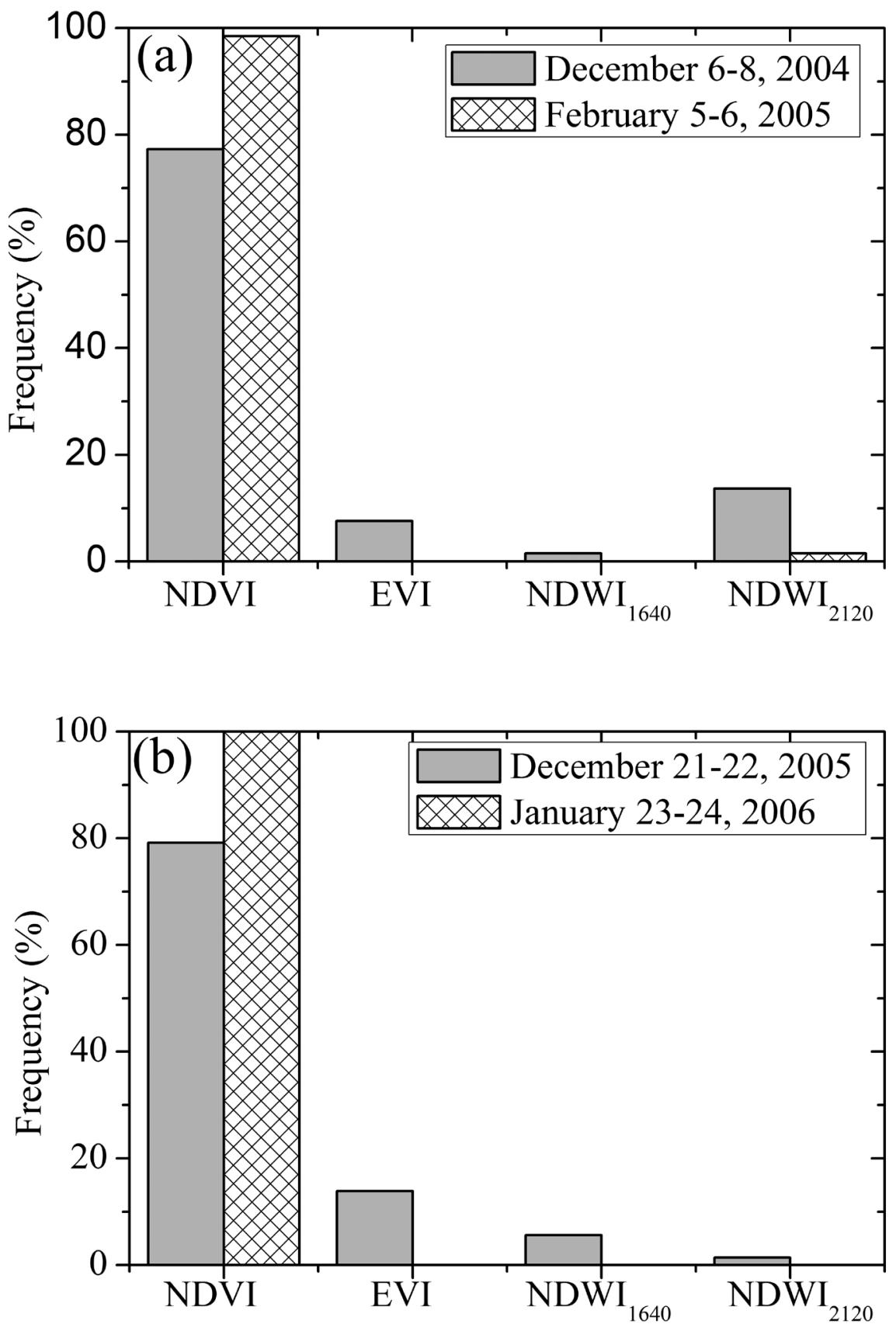

Figure 7 - Frequency of the pixels with the lowest sensible vegetation indices (angular differences) to directional effects for incomplete (December) and closed (January- February) soybean canopies in the (a) 2004-2005 and (b) 2005-2006 growing seasons. 
In spite of the soybean development stage, the reflectance of the first seven MODIS bands was higher in the backscattering due to the predominance of sunlit canopy components for the MODIS. However, except for the EVI, vegetation indices such as the NDVI and NDWIs had larger values in the forward scattering direction. Directional effects were reduced after the vegetation index determination, but they were still significant. Such effects decreased with canopy closure. The NDVI was lesser affected by directional effects than the EVI, NDWI ${ }_{1640}$ and $\mathrm{NDWI}_{2120}$. The NDVI presented the smallest differences between the backscattering and forward scattering directions for fixed phenological stages.

Due to cloud cover and the difficulty of using the MODIS Main Algorithm to estimate soybean biophysical attributes such as LAI, results suggested that the NDVI was the best option to empirically obtain such estimates because it was lesser sensible to viewing geometry than the other studied indices.

\section{ACKNOWLEDGMENTS}

The authors are grateful to Grupo André Maggi for providing the agronomical data used in this investigation. Thanks are also due to some Brazilian science foundations: Fundação de Amparo à Pesquisa do Estado de São Paulo (FAPESP) (grant 2008/11499-8), Coordenação de Aperfeiçoamento de Pessoal de Nível Superior (CAPES), and Conselho Nacional de Desenvolvimento Científico e Tecnológico (CNPq). Comments by the reviewers were highly appreciated.

\section{RESUMO}

Efeitos direcionais introduzem variabilidade na reflectância e na determinação de índices de vegetação, especialmente quando sensores de amplo campo de visada são usados (p.ex., Moderate Resolution Imaging Spectroradiometer - MODIS). Neste estudo, nós avaliamos os efeitos direcionais sobre a reflectância e quatro índices de vegetação (Normalized Difference Vegetation Index - NDVI; Enhanced Vegetation Index - EVI; Normalized Difference Water Index - NDWI 1640 e $\mathrm{NDWI}_{2120}$ ), calculados a partir de dados MODIS, em função do crescimento da soja em duas estações agrícolas (2004-2005 e 2005-2006). Para manter o estádio reprodutivo de uma dada variedade como um fator constante, variando a geometria de visada, pares de imagens obtidas em datas próximas e com ângulos de visada opostos foram analisados. Usando uma abordagem estatística não-paramétrica com análise bootstrapping e normalizando os índices para suas diferenças angulares entre as direções de visada, sua sensibilidade para os efeitos direcionais foi estudada. Os resultados mostraram que a variação da reflectância do MODIS entre estádios fenológicos consecutivos foi geralmente menor do que aquelas resultantes da geometria de visada para dosséis fechados. O contrário foi observado para dosséis esparsos. A reflectância das primeiras sete bandas do MODIS foi maior na direção de retro-espalhamento. Exceto o EVI, os demais índices de vegetação tiveram maiores valores na direção de espalhamento frontal. Os efeitos direcionais diminuíram com o fechamento do dossel. O NDVI foi menos afetado pelos efeitos direcionais do que os demais índices, apresentando as menores diferenças entre as direções de visada para os mesmos estádios fenológicos.

Palavras-chave: NDWI, EVI, NDVI, sensoriamento remoto, efeitos direcionais.

\section{REFERENCES}

Aparicio N, Villegas D, Royo C, Casadeus J And Araus JL. 2004. Effect of sensor view angle on the assessment of agronomic traits by ground level hyper-spectral reflectance measurements in durum wheat under contrasting Mediterranean conditions. Int J Remote Sens 25: 1131-1152.

Chen D, HuAng J And JACKSON TJ. 2005. Vegetation water content estimation for corn and soybeans using spectral indices derived from MODIS near- and short-wave infrared bands. Remote Sens Environ 98: 225-236.

DORAISWAMY PC, SINCLAIR TR, HOLLINGER S, AKHMEDOV B, STERn A AND PRUEGER J. 2005. Application of MODIS derived parameters for regional crop yield assessment. Remote Sens Environ 97: 192-202.

DWYER J AND SCHMIDT G. 2006. The MODIS reprojection tool. In: Qu JJ ET AL. (Eds), Earth Science Satellite Remote Sensing, Berlin: Springer, Berlin, Germany, p. 162-177. 
EPIPHANIO JCN AND HUETE AR. 1995. Dependence of NDVI and SAVI on sun/sensor geometry and its effect on fAPAR relationships in Alfalfa. Remote Sens Environ 51: 351-360.

GALVÃo LS, RoBERTS DA, FormagGio AR, NumATA I AND BREUNIG FM. 2009. View angle effects on the discrimination of soybean varieties and on the relationships between vegetation indices and yield using off-nadir Hyperion data. Remote Sens Environ 113: 846-856.

GAO B. 1996. NDWI - A normalized difference water index for remote sensing of vegetation liquid water from space. Remote Sens Environ 58: 257-266.

Gao X, Huete A AND DidAn K. 2003. Multisensor comparisons and validation of MODIS vegetation indices at the semiarid Jornada experimental range. IEEE Trans Geosci Remote Sens 41: 2368-2381.

Huete AR, Didan K, Miura T, Rodriguez EP, Gao X and FERREIRA LG. 2002. Overview of the radiometric and biophysical performance of the MODIS vegetation indices. Remote Sens Environ 83: 195-213.

JACKSON TJ, CHEN D, COSH M, LI F, ANDERSON M, WALTHALL C, Doriaswamy P AND RAY Hunt E. 2004. Vegetation water content mapping using Landsat data derived Normalized Difference Water Index for corn and soybeans. Remote Sens Environ 92: 475-482.

JiAng B, LiAng S, WANG J AND XIAO Z. 2010. Modeling MODIS LAI time series using three statistical methods. Remote Sens Environ 114: 1432-1444.

JiAng Z, HuEte A, DidAn K AND MiURA T. 2008. Development of a two-band Enhanced Vegetation Index without a blue band. Remote Sens Environ 112: 3833-3845.

KNYAZIKHIN Y, MARTONCHIK JV, MYNENI RB, DINER DJ AND RUNNING SW. 1998. Synergistic algorithm for estimating vegetation canopy leaf area index and fraction of absorbed photosynthetically active radiation from MODIS and MISR data. J Geophys Res 103: 32257-32276.

LEBLON B, GALlant L AND GRANBERG H. 1996. Effects of shadowing types on ground-measured visible and nearinfrared shadow reflectances. Remote Sens Environ 58: $322-328$
Meyer D, Verstraete M And Pinty B. 1995. The effect of surface anisotropy and viewing geometry on the estimation of NDVI from AVHRR. Remote Sens Rev 12: 3-27.

Miura T, Huete AR AND YoshiokA H. 2000. Evaluation of sensor calibration uncertainties on vegetation indices for MODIS. IEEE Trans Geosci Remote Sens 38: 1399-1409.

MYNENI RB ET AL. 2002. Global products of vegetation leaf area and fraction absorbed PAR from year one of MODIS data. Remote Sens Environ 83: 214-231.

MYNENI RB AND WiLliams DL. 1994. On the relationship between FAPAR and NDVI. Remote Sens Environ 49: 200-211.

RIZZI R AND RUDORFF BFT. 2007. MODIS sensor images associated with an agronomic model to estimate soybean grain yield. Pesq Agropec Bras 42: 73-80.

RizzI R, RUdorfF BFT, SHIMABUKURO YE AND DORAISWAMY PC. 2006. Assessment of MODIS LAI retrievals over soybean crop in Southern Brazil. Int J Remote Sens 27: 4091-4100.

Rouse JW, HAAS RH, SCHELl JA AND DEERING DW. 1973. Monitoring vegetation systems in the Great Plains with ERTS. In: Earth Resources Technology Satellite-1 Symposium, 3, FREDEN SC, MERCANTI EP and FRIEDMAN DB (Ed), Washington- DC Proceedings...., STANLEY C ET AL. Washington- DC, p. 309-317.

Walter-Shea EA, Privette J, Cornell D, Mesarch MA AND HAYS CJ. 1997. Relations between directional spectral vegetation indices and leaf area and absorbed radiation in Alfalfa. Remote Sens Environ 6: 162-177.

WARDLEY NW. 1984. Vegetation index variability as a function of viewing geometry. Int J Remote Sens 5: 861-870.

WILCOXON F. 1945. Individual Comparisons by Ranking Methods. Biometrics Bull 1: 80-83.

XIONG X, ChE NZAND BARNeS W. 2005. Terra MODIS on-orbit spatial characterization and performance. IEEE Trans Geosci Remote Sens 43: 355-365.

YI Y, YANG D, HUANG J AND CHEN D. 2008. Evaluation of MODIS surface reflectance products for wheat leaf area index (LAI) retrieval. ISPRS J Photogramm Remote Sens 63: 661-677. 